\title{
Persistent Stunting in Middle Childhood: The Case of Andhra Pradesh Using Longitudinal Data
}

\author{
Rozana Himaz*
}

\begin{abstract}
This article looks at what observable characteristics influence a child being persistently stunted, moving from being stunted or moving into being stunted in middle childhood, between 7 and 12 , using longitudinal data for Andhra Pradesh. It finds the key factors that help a child move out of being stunted are mother's education and coming from the more prosperous region of Coastal Andhra. In contrast, the key factors that pushed a child into being stunted were the child being a girl and being a younger sibling. We also find that children who moved out of being stunted consume a diet higher in protein and micronutrients than others. The article suggests that even if a child starts middle childhood with significant shortfalls in height accrued from earlier on in life, nutritional interventions and adult female education may have a positive impact on linear growth and perhaps mitigate consequences of early age stunting.
\end{abstract}

\section{Introduction}

India contains a bulk of global infant undernutrition with around 46 per cent of children under three 'stunted' in 1998/99 (the latest year for which nationally representative data is available, Gragnolati et al. 2008). ${ }^{1}$ The adverse impact of early age stunting on various outcomes later on in terms of health, productivity, cognitive development and schooling achievement have been well established in the literature (GranthamMcGregor et al. 1997, 1999; Dercon and Sanchez 2008). The focus of most papers on stunting, however, is the under five age group. This is not surprising, as stunting is argued to occur within the first few years of life (Martorell et al. 1994). Children enter middle childhood (roughly between the ages of 7-12), with nutritional deficits accrued earlier on and are likely to follow the same growth path, continuing to be 'stunted'. However, although middle childhood is a period where children experience a slower phase of growth (Tanner 1990), there is evidence that an already stunted child may 'catch up' given a suitable environment, adoption, emigration or treatment of disease that may have retarded growth (Golden 1993; Tanner 1986). Quite in contrast, children may also falter in terms of linear growth, increasing the prevalence of stunting with age. This is emerging as a key issue in recent data available for sub-Saharan Africa (Friedman et al. 2005; Lwambo et al. 2000; Monyeki et al. 2000, Stoltzfus et al. 1997).

This article attempts to add to this recent strand in the literature by looking at how undernutrition seems to have persisted in middle childhood in Andhra Pradesh, India, using longitudinal data. It looks particularly at what observable factors contributed towards the persistence of stunting (i.e. following a 'stable' growth path of continuing to be stunted) and in contrast what helped children move out of or into being stunted between the ages of 7 and 12 . The article offers a unique contribution to the literature in this area, as there is no other paper in the empirical literature, as far as the author is aware, that looks at this issue for India using longitudinal data. The article is also unique in that it looks at the lives of persistently stunted children using a rich dataset that provides information on several conventional and unconventional aspects: what types of households they are from, what their typical diet contains, 


\begin{tabular}{llll}
$\begin{array}{l}\text { Not stunted in } \\
\text { either round }\end{array}$ & $\begin{array}{l}\text { Stunted in } \\
\text { both rounds } \\
\text { ('persistent') }\end{array}$ & $\begin{array}{l}\text { Stunted in } \\
\text { Round } 1 \text { but }\end{array}$ & $\begin{array}{l}\text { not Rount } 2 \\
\text { ('mound } 2 \text { but not }\end{array}$ \\
& & Round 1 ('moved out') & in') \\
\hline
\end{tabular}

\begin{tabular}{|c|c|c|c|c|}
\hline \multicolumn{5}{|l|}{ Child characteristics } \\
\hline Height for age z-score (Round 1) & -0.95 & $-2.78^{* *}$ & $-2.42^{* *}$ & $-1.50^{*}$ \\
\hline Height for age z-score (Round 2) & -0.96 & $-2.61^{* *}$ & $-1.49^{*}$ & $-2.35^{* *}$ \\
\hline Body mass index (Round 2) & -1.25 & $-1.87^{* *}$ & $-1.65^{*}$ & $-1.44^{*}$ \\
\hline Boys $(\%)$ & 0.49 & 0.52 & 0.56 & $0.31^{* *}$ \\
\hline \multicolumn{5}{|l|}{ Caregiver characteristics } \\
\hline Main caregiver is not mother or father (\%) & 3 & $5^{*}$ & 1 & 4 \\
\hline Father's education (years) & 4.98 & $3.70^{* *}$ & 5.25 & $3.66^{* *}$ \\
\hline Mother's education (years) & 3.18 & $1.54^{* *}$ & 3.28 & $1.92^{* *}$ \\
\hline \multicolumn{5}{|l|}{ Caste $(\%)$} \\
\hline SC & 20 & 21 & 14 & 17 \\
\hline ST & 8 & $12^{* *}$ & 09 & $15^{* *}$ \\
\hline $\mathrm{BC}$ & 46 & 51 & 54 & 50 \\
\hline OC & 23 & $13^{* *}$ & 20 & $15^{*}$ \\
\hline \multicolumn{5}{|l|}{ Wealth, expenditure, vulnerability } \\
\hline Wealth index (Round 1) & 0.39 & $0.28^{* * *}$ & $0.35^{*}$ & $0.33^{* *}$ \\
\hline Wealth index (Round 2) & 0.32 & $0.34^{*}$ & 0.32 & 0.30 \\
\hline $\begin{array}{l}\text { Description of household compared to } \\
\text { others (Round 2) }\end{array}$ & About average & $\begin{array}{l}\text { Poorer than } \\
\text { average }\end{array}$ & About average & $\begin{array}{l}\text { Poorer than } \\
\text { average }\end{array}$ \\
\hline Adjusted per capita expenditure (Rupees) & 720 & 723 & 675 & 727 \\
\hline $\begin{array}{l}\text { Households that had a food shortage in the } \\
12 \text { months before Round } 2(\%)\end{array}$ & 8 & $15^{* *}$ & 9 & 7 \\
\hline $\begin{array}{l}\text { Suffered a serious environmental hazard } \\
\text { such as a flood, drought, pest invasion, fire, } \\
\text { collapse of building, crop failure between } \\
\text { rounds (\%) }\end{array}$ & 56 & $79^{*}$ & 61 & $66^{*}$ \\
\hline In serious debt at Round 2 (\%) & 49 & $56^{*}$ & 47 & 52 \\
\hline \multicolumn{5}{|l|}{ Budget shares of expenditure } \\
\hline Alcohol and tobacco share (\%) & 1 & $2^{*}$ & 1 & 1.5 \\
\hline Number of observations & 610 & 224 & 82 & 92 \\
\hline
\end{tabular}

Source Young Lives, India (Andhra Pradesh) Older cohort data, Round 1 and Round 2 for 2002 and 2006.

how they perceive their own lives (subjective wellbeing) and their psychosocial outcomes (such as self-esteem, self-efficacy and sense of inclusion).

\section{Data}

The data for this article comes from a unique panel survey of 1,000 children (one child per household, referred to as the 'index child' in this article), their communities and households conducted in Andhra Pradesh, India in 2002 and 2006, drawn from a pro-poor sample managed by the Young Lives project (University of Oxford). The survey was carried out across 20 sentinel sites in three regions. ${ }^{2}$ The children were aged seven to eight years of age in 2002 (Round 1) and 11-12 at Round 2.

The article looks at three groups of children: (1) those who were stunted (i.e. have height for age $z$-scores of below 2 standard deviations of the mean) in Round 1 and continued to be stunted four years later in Round 2. In Round 1, 31 per cent of the children were stunted and over 70 per 
cent of them continued to be stunted in Round 2 (i.e. 224 children). While a majority of children remained 'stunted', a sizeable proportion (30 per cent) had moved out of being stunted by Round 2 . These 82 children form the second group we examine. The final group is one of 92 children (nearly 10 per cent of the sample) who were not stunted in Round 1 but were stunted by Round $2 .{ }^{3}$

The analysis uses descriptive statistics, multivariate regressions and results from other papers using Young Lives data to glean insights as to what observables may explain such different growth trajectories for stunted children in middle childhood.

\section{Analyses}

\subsection{Descriptive statistics}

Table 1 shows child and household characteristics for the three groups of children compared to those children who were never below 2 standard deviations of the mean in terms of height for age z-scores. One of the first things to notice is that the height for age of all three groups (columns 2, 3 and 4) are significantly lower than that of the comparison group of children (column 1) who were never stunted in our data. This reflects that even if the children moved in/out of being stunted in middle childhood, they remain a group that are significantly worse off in terms of their linear growth compared to those never stunted by the time they entered middle childhood.

The parents of persistently stunted children and those who move into being stunted are significantly less educated. Quite interestingly, the education levels of parents of children who moved out of being stunted are not significantly different to that of the never stunted group.

Similar results are found for statistics regarding caste: persistent stunting and moving into being stunted in middle childhood is significantly more prevalent among Scheduled Tribes (ST) and less so in other castes (OC). However, the caste distribution of children who move out of being stunted is not significantly different to that of the comparison group in column 1 of children never stunted.

Similarly, households with a child who is persistently stunted or moved into stunting by Round 2 consider themselves poorer than average in Round 2. But households with a never stunted child or those with a child that moved out of being stunted consider themselves 'about average'. This perception is not reflected in the wealth index figure for Round 2 or the per capita expenditure figures. ${ }^{4}$

Although the per capita expenditure figures are not significantly different among the groups, households with a persistently stunted child or a child that moved into being stunted by Round 2 seem to have been subject to significantly more adverse shocks between rounds. For example, more households with a stunted child report to have had a food shortage within the past 12 months (15 per cent vs. 8 per cent); a significantly higher proportion are in serious debt compared with households with a child who is not stunted (56 per cent vs. 48 per cent) and a significant proportion (79 per cent vs. 56 per cent) had suffered from a serious environmental hazard such as drought, flood or crop failure.

Moreover, although per capita expenditure figures for Round 2 do not show a significant difference between the households, per capita incomes are significantly different between these households in Round 2 to the detriment of households with a stunted child at Rs. 439.70 vs. Rs. 613.50. The gap in expenditure and income may be explained by the fact that a higher proportion of households with a stunted child claim to benefit from charity, food aid, debts ${ }^{5}$ and access to government programmes, ${ }^{6}$ that probably help them consume much more than they claim to earn. ${ }^{7}$

Households with a persistently stunted child also spend significantly more on alcohol and tobacco consumption (2 per cent vs. 1 per cent). Neufeld et al. (2005) show, using India's National Sample Survey for 1995-6, that higher alcohol and tobacco consumption is correlated strongly with poorer households from rural areas as well as those from scheduled castes and tribes. Prasad (2009) argues that alcohol consumption is rising in India with more than half of all drinkers falling into the criteria for hazardous drinking, which is characterised by bingeing and solitary consumption to the point of intoxication. It remains to be explored further how much household alcohol consumption has an impact on child health outcomes and whether this issue has to be a direct focus of policy. 
Table 2 shows that the mothers of stunted children are also significantly shorter and lighter than the mother's of non-stunted children. While this is partly indicative that genetic factors may be driving child height, it is also suggestive of the fact that stunting and poor nourishment is likely to be a problem transmitted through generations with poorly fed anaemic mothers giving birth to underweight children who are also likely to be malnourished. Stunted children are also more likely to have long-term health problems than non-stunted children (10 per cent vs. 5 per cent) and consider their health to be significantly worse than that of their peers (unreported).

The stunted children eat a less diverse diet than the non-stunted children, with a significantly lower consumption of fruits, roots, tubers and sugary food. Quite notably, a significantly larger proportion of children who moved out of being stunted had a diet containing legumes (such as lentils and beans that are high in protein) and fish or seafood. A significantly lower proportion had cereals and sugary food. The data on diet pertains to consumption in the 24 hours before the survey, but indicates that children who moved out of stunting may have consumed diets higher in protein than the other groups.

The children who were stunted in Round 1 were reported to be more often unhappy, tearful and downhearted than non-stunted children. They also felt they were less liked by other children than did their non-stunted counterparts. These poorer outcomes have persisted over the four years up to the time of the second round of data collection, with these children scoring lower in terms of subjective wellbeing (perception of how good life is, based on a ladder of 1-9, with 1 denoting the worst possible outcome and 9 the best), sense of optimism about the future (reflected in a lower ladder rung four years from now), low self-esteem (an opinion about oneself), and sense of inclusion. Even the caregivers of the persistently stunted children seem to be suffering from a low sense of inclusion compared with the caregivers of children who were never stunted. ${ }^{8}$

Dercon and Sanchez (2008) find clear evidence that stunting early on in childhood has serious adverse effects on a child's cognitive and psychosocial abilities later on at age 12, in all four Young Lives countries: Ethiopia, Peru, Vietnam and India.

\subsection{Regression analysis}

Table 3, column 1 shows that the key observable characteristics at Round 1 that exerted a positive significant influence on a child's height for age z-score in Round 2 was the child's gender being male, the mother's height (capturing partly genetic factors as well as the mother's accumulated investments in health that have an impact on child health, especially prenatally), the mother's education and household wealth. The significant negative influences come from belonging to a scheduled tribe or backward caste compared with coming from 'other' castes and rural residence. Column 2 looks at round two heights as explained by Round 2 characteristics. The results are the same as in the previous column except that household wealth (now proxied by expenditure per capita) ceases to be significant. This makes sense in the context that short-term household expenditure is unlikely to have an impact on a child's height which reflects long term investments in health.

Column 3 looks at what might explain a child remaining stunted through middle childhood. The significant negative influences are the mother's height and education. The significant positive influences are coming from a scheduled caste or backward caste (compared to coming from other castes) and coming from Rayalaseema, a relatively poor area compared to Telangana.

Column 4 looks at what factors helped a child move out of being stunted compared with the group of children who remain stunted in both rounds. The key contributing factors are the mother's education and coming from Coastal Andhra - a state relatively more affluent than the omitted group Telangana. The main factors that push a child to being stunted between rounds compared with the group that were never stunted are being a girl and having a higher birth order (column 5).

Note that the regression results are not different in terms of sign and significance if we re-run it separately for boys and girls, apart from for column 1, when household size and birth order become important for determining a girl's height for age.

The regressions here do not account for the fact that within the different groups of children linear growth between rounds may have been 


\begin{tabular}{|c|c|c|c|c|}
\hline & $\begin{array}{l}\text { Not stunted } \\
\text { in either } \\
\text { round }\end{array}$ & $\begin{array}{l}\text { Stunted in } \\
\text { both rounds } \\
\text { ('persistent') }\end{array}$ & $\begin{array}{l}\text { Stunted in } \\
\text { Round } 1 \text { but } \\
\text { not Round } 2 \\
\text { ('moved out') }\end{array}$ & $\begin{array}{l}\text { Stunted in } \\
\text { Round } 2 \text { but not } \\
\text { Round } 1 \text { ('moved } \\
\text { in') }\end{array}$ \\
\hline \multicolumn{5}{|l|}{ Health } \\
\hline Mother's weight (kg) & 50.43 & $46.75^{*}$ & $47.3^{*}$ & 46.02 \\
\hline Mother's height (cm) & 151.22 & $148.92^{*}$ & 150.64 & 149.92 \\
\hline Child has long-term health problem (\%) & 5 & $10^{* *}$ & 7 & 5 \\
\hline \multicolumn{5}{|l|}{$\begin{array}{l}\text { Proportion that consume the following } \\
\text { food groups in the last } 24 \text { hours before } \\
\text { the survey: }\end{array}$} \\
\hline Cereals (maize, rice, bread) & 0.99 & 0.99 & $0.97^{*}$ & 1 \\
\hline Roots/tubers (potato, cassava) & 0.37 & $0.27^{* *}$ & 0.43 & 0.35 \\
\hline Legumes (lentils, beans, peas) & 0.42 & 0.42 & $0.56^{* *}$ & 0.38 \\
\hline Milk, milk products & 0.66 & 0.62 & 0.60 & 0.67 \\
\hline Eggs & 0.16 & 0.15 & 0.19 & 0.10 \\
\hline Meat/offal & 0.08 & 0.07 & 0.13 & 0.10 \\
\hline Fish/seafood & 0.04 & 0.04 & $0.12^{* *}$ & 0.05 \\
\hline Oil/fat & 0.95 & 0.95 & 0.96 & 0.97 \\
\hline Sugar/honey & 0.77 & $0.70^{* *}$ & $0.66^{* *}$ & 0.76 \\
\hline Fruits & 0.39 & $0.28^{* *}$ & 0.36 & 0.37 \\
\hline Vegetables & 0.95 & 0.96 & 0.95 & $0.91^{*}$ \\
\hline \multicolumn{5}{|l|}{ Subjective wellbeing and psychosocial outcomes } \\
\hline $\begin{array}{l}\text { Often unhappy, downhearted or } \\
\text { tearful (\%) }\end{array}$ & 22 & $34^{* *}$ & 28 & 30 \\
\hline Generally liked by other children (\%) & 95 & $91^{* *}$ & 95 & 93 \\
\hline $\begin{array}{l}\text { Easily distracted, concentration } \\
\text { wanders (\%) }\end{array}$ & 30 & 37 & 32 & 29 \\
\hline \multicolumn{5}{|l|}{ Round 2: } \\
\hline Ladder (scale 1-9: 1, worst; 9, best) & 3.73 & $3.01^{* *}$ & 3.58 & 3.39 \\
\hline Ladder four years from now & 5.12 & $4.01^{*}$ & 4.85 & $4.68^{*}$ \\
\hline $\begin{array}{l}\text { Child self-esteem (based on a } \\
\text { standardised index with mean zero and } \\
\text { variance 1) }\end{array}$ & 0.01 & $-0.04^{*}$ & -0.01 & 0.03 \\
\hline Child self-efficacy & -0.04 & 0.01 & -0.05 & 0.06 \\
\hline Child sense of inclusion & -0.00 & $-0.07^{* *}$ & 0.06 & 0.05 \\
\hline Caregiver's sense of inclusion & 0.02 & $-0.05^{*}$ & 0.04 & 0.00 \\
\hline Number of observations & 600 & 224 & 82 & 92 \\
\hline
\end{tabular}

*Significant at the 10 per cent level ${ }^{*}$ Significant at the 5 per cent level or higher

Note The PPVT score is based on the Peabody picture vocabulary test administered to children in the Young Lives sample, along with a maths test. See Ceuto et al. (2009) for more details on the tests.

Source Young Lives, India (Andhra Pradesh) Older cohort data, Round 1 and Round 2 for 2002 and 2006.

driven due to different reasons and that growth may have occurred at different speeds. To account for this, similar regressions are run with the difference in height for age between rounds as the dependent variable explained by the same Round 1 variables. In this case, the only variables 
Table 3 Determinants of height for age in Round 2, persistent stunting, moving out of/into being stunted

\begin{tabular}{|c|c|c|c|c|c|}
\hline Dependent variable & $\begin{array}{l}\text { Height for age } \\
\text { z-score } \\
\text { (Round 2) }\end{array}$ & $\begin{array}{l}\text { Height for age } \\
\text { z-score } \\
\text { (Round 2) }\end{array}$ & $\begin{array}{l}\text { Persistently } \\
\text { stunted }\end{array}$ & Moved out & Moved in \\
\hline Gender & $0.174(2.90)^{* *}$ & $0.156(1.88)^{*}$ & $0.033(1.18)$ & $-0.012(0.19)$ & $-0.082(3.59)^{* *}$ \\
\hline Birth order & $-0.033(1.23)$ & $-0.044(1.27)$ & $0.012(0.76)$ & $0.021(0.97)$ & $0.028(2.35)^{*}$ \\
\hline Mother's height & $0.035(5.95)^{* * *}$ & $0.035(5.73)^{* * *}$ & $-0.016(4.74)^{* *}$ & $0.005(0.64)$ & -0.005 (1.64) \\
\hline Household size & $-0.155(1.05)$ & $-0.032(1.50)$ & $0.004(0.06)$ & $0.104(1.14)$ & $0.007(0.13)$ \\
\hline Father's education & $-0.007(0.90)$ & $-0.003(0.38)$ & $0.008(1.63)$ & $-0.001(0.20)$ & $0.000(0.11)$ \\
\hline Mother's education & $0.039(4.02)^{* * *}$ & $0.043(4.27)^{* * *}$ & $-0.019(3.34)^{* *}$ & $0.031(2.17)^{*}$ & $-0.003(1.25)$ \\
\hline Wealth index & $0.458(2.45)^{* *}$ & & $-0.125(1.33)$ & $(1.43)$ & $-0.118(1.30)$ \\
\hline Scheduled caste & $-0.070(0.48)$ & $-0.079(0.54)$ & $0.061(1.20)$ & $-0.073(0.72)$ & $-0.020(0.37)$ \\
\hline Scheduled tribe & $-0.330(2.77)^{* *}$ & $-0.369(3.11)^{* * *}$ & $0.155(2.66)^{* *}$ & $-0.090(0.88)$ & $(0.96)$ \\
\hline Backward caste & $-0.199(1.91)^{*}$ & $-0.197(1.80)^{*}$ & $0.133(3.52)^{* *}$ & $-0.031(0.35)$ & $0.036(1.39)$ \\
\hline Rural & $-0.133(1.71)^{*}$ & $-0.186(2.13)^{* *}$ & $0.020(0.64)$ & $0.013(0.20)$ & $-0.007(0.37)$ \\
\hline Coastal & $0.037(0.57)$ & $0.054(0.71)$ & $-0.022(0.58)$ & $0.150(2.12)^{* *}$ & $0.037(1.29)$ \\
\hline Rayalaseema & $-0.098(1.12)$ & $(1.24)$ & $0.080(2.27)^{*}$ & $0.080(1.46)$ & $0.045(1.08)$ \\
\hline Per capita expenditure & & $-0.000(0.74)$ & & & \\
\hline Constant & $-6.314(7.05)^{* *}$ & $-6.208(7.22)^{* *}$ & & & \\
\hline Observations & 895 & 895 & 737 & 269 & 634 \\
\hline$R$-squared & 0.15 & 0.14 & & & \\
\hline
\end{tabular}

*Significant at the 10 per cent level **Significant at the 5 per cent level ***Significant at the 1 per cent level

Note Column 1 shows OLS regression results (errors corrected for clustering) with height for age z-scored in Round 2 as the dependent variable and independent variables for Round 1 . Column 2 is similar to column 1 with the only difference being that explanatory variables are based on Round 2 data. Column 3 shows probit regression results (with marginal effects reported) of the determinants of persistent stunting. The dependent variable is equal to 1 if the child was stunted in both rounds and $\mathrm{O}$ if the child was not stunted is both rounds. Column 4 shows probit regression (with marginal effects reported) of the determinants of what moves a child from being stunted in Round 1 to not being stunted in Round 2. Dependent variable equals 1 if a child was stunted in Round 1 but not so in Round 2 and $\mathrm{O}$ if a child was stunted in both rounds. Column 5 shows probit regression (with marginal effects reported) of the determinants of what moves a child into being stunted in Round 2, although the child was not stunted in Round 1. Dependent variable equals 1 if a child was stunted in Round 2 but not so in Round 1 and 0 if a child was not stunted in both rounds. Independent variables are based on Round 1 data for Columns 1, 3, 4 and 5. All regressions included household demographic composition by gender.

Source Young Lives older cohort data for Rounds 1 and 2 (2002 and 2006).

that seem to have a positive impact on the difference is that the child is male and comes from Rayalaseema. Thus, boys seem to have a faster velocity of growth between Rounds 1 and 2 in our sample as well as children from Rayalaseema. Whether this is due to the inherently different ways in which boys and girls grow during middle childhood or some other reason, is unclear.

\section{Conclusions}

This article looked at what observable characteristics influenced a child being persistently stunted, moving out of being stunted or moving into being stunted in middle childhood between the ages of 7 and 12 .

The article found that on average, children who were persistently stunted throughout middle 
childhood came from households that are typically poorer in terms of earnings; more vulnerable to food shortage and shocks such as droughts and crop failure; are more likely to be in serious debt and more likely to be indebted to money lenders; have parents with poorer education; mothers with lower anthropometric outcomes who felt less included in their communities; are more likely to belong to a scheduled tribe or backward caste and from rural areas. The households also spent a larger budget share on alcohol and tobacco. In contrast, household characteristics of those that managed to move out of being stunted in middle childhood were not significantly different to that of households with an index child that was never stunted in many respects, including parents' education, exposure to shocks between the rounds and even psychosocial and subjective wellbeing outcomes. Interestingly, more children who moved out of being stunted seemed to be consuming a diet higher in protein rich food than those never stunted or the other groups.

The article also found, uniquely, that children who were persistently stunted had lower psychosocial outcomes such as self-esteem and sense of inclusion, as well as a lower perception of their current situation in life that those who were never stunted.

The key factors that help a child move out of being stunted are mother's education and

\section{Notes}

* This article is based mainly on data from the Young Lives project. Young Lives is core-funded by the UK Department for International Development (DFID) for the benefit of developing countries. Sub-studies are funded by IDRC (in Ethiopia), UNICEF (in India), the Bernard van Leer Foundation (in India and Peru) and Irish Aid (in Vietnam). The views expressed here are those of the author(s). They are not necessarily those of the Young Lives project, the University of Oxford, DFID or other funders. The author wishes to thank Lawrence Haddad for very helpful comments on an earlier version of this article. The usual disclaimer applies.

1 A child is stunted when his/her linear growth accumulation measured by height for age falls significantly below the international reference coming from Coastal Andhra, while the key factors that pushed a child into being stunted, worsening the gap between individual height for age and the international reference, were the child being a girl and being a younger sibling.

Thus, this article suggests although children may start middle childhood with stunting accrued from earlier on in life, as many as 30 per cent can move out of being stunted in middle childhood with observable characteristics such as mother's education being a strong influence in making this happen. It also shows that girls and younger siblings in the family can be particularly vulnerable to being pushed into being stunted in middle childhood, although they were not previously. These issues carry significant policy implications. They suggest, for example, that nutritional interventions and adult female education aimed at improving health in middle childhood may indeed have a positive impact on child linear growth and perhaps mitigate adverse consequences of early age stunting. Indeed, Singh (2008) using Young Lives data shows that the midday meal scheme in India targeting school age children does indeed improve both health and cognitive outcomes in children. The issue of interventions in middle childhood to improve linear growth and move children out of being stunted and its impact on other aspects of child wellbeing and future productivity, therefore, is an area that needs careful further investigation.

mean making the child among the shortest 2 per cent in his/her age group.

2 The three regions were Telangana, Rayalaseema and Coastal Andhra. See Galab et al. (2008), Ch. 2, for further details about how the sample was selected and go to: www.younglives.org for further information about the project, low survey attrition, etc.

3 This article uses the conventional definition for stunting as a tool to refer to an improvement or worsening of linear growth, in order to see what observables can help children who seem to the worst off in terms of undernutrition. The focus therefore is on what helps arguably the most undernourished group of children, rather than the 'average' child.

4 The wealth index ranges from 0 to 1 and is calculated as the simple average of the 
housing quality index (calculated as scaled values $(0-1)$ of rooms per person, wall, roof and floor durability divided by 4 ), consumer durables index (calculated as scaled values (0-1) of radio, fridge, bicycle, TV, motorbike/scooter, motor car/truck, mobile phone, landline phone, modern bed, table or chair and sofa divided by 11 and the service index (calculated as scaled values $(0-1)$ of electricity, water, sanitation and cooking fuel divided by 4 ).

5 Data from Round 1 indicates that around 57 per cent of households with a stunted child were in serious debt (as opposed to 42 per cent from the other group) and that 76 per cent of them obtained it from a money lender (as opposed to 23 per cent in the other group). Most households with a non-stunted index child claimed they had access to formal sources of credit. These figures were roughly the same in Round 2.

\section{References}

Cueto, S.; Juan, L. and Guerrero, G. (2009) Psychometric Characteristics of Cognitive Development and Achievement Instrument in Round Tiwo of Young Lives, Technical Note 15, Oxford: Young Lives

Dercon, S. and Krishnan, P. (2009) Poverty and the Psychosocial Competencies of Children: Evidence from the Young Lives Sample in Four Developing Countries, Oxford: Young Lives Working Paper series

Dercon S. and Sanchez, A. (2008) Poverty, Malnutrition and its Psychosocial Impact on Children, Working Paper 39, Oxford: Young Lives

Friedman J.F.; Phillips-Howard, P.A.; Mirel, L.B.; Terlouw, D.J.; Okello, N.; Vulule, J.M.; Hawley, W.A.; Nahlen, B.L. and Ter Kuile, F. (2005) 'Progression of Stunting and its Predictors Among School-aged Children in Western Kenya', European Journal of Clinical Nutrition 59: 914-22

Galab, S.; Reddy, P. and Himaz, R. (2008) Young Lives Round 2 Survey Report. Initial Findings: Andhra Pradesh, India, Oxford: Young Lives

Golden, M.H.N. (1993) 'Is Complete Catch-up Possible for Stunted Malnourished Children? Causes and Mechanisms of Linear Growth Retardation', Proceedings of an IDEGG Workshop held in London, 15-18 January Gragnolati, M.; Shekar, M. and Dasgupta, M. (2008) India's Undernourished Children: A Call for Reform and Action, Washington DC: World Bank
6 Significantly more households in our sample with a persistently stunted child claim to use the Public Distribution System for the purchase of rice (99 per cent vs. 97 per cent), received money or goods from food aid over the past 12 months ( 90 per cent vs. 83 per cent) and received aid from an NGO or charity ( 6 per cent vs. 3 per cent).

7 It could of course also point to significant under-reporting of earnings, possibly more among households with stunted children that seem to engage more in casual employment. We do not deal with this issue in this study.

8 See Dercon and Krishnan (2009) for how these normalised indices with a mean of 0 and variance of 1 are calculated, based on various groups of questions that attempted to assess a child's psychosocial outcomes at age 12 .

Grantham-McGregor, S.; Fernald, L. and Sethuraman, K. (1999) 'Effects of Health and Nutrition in Cognitive and Behavioural Development in Ghildren in the First Three Years of Life: Part 1', Food and Nutrition Bulletin 20: 53-75

Grantham-McGregor, S.; Walker, C.; Chang, S. and Powell, C. (1997) 'Effects of Early Childhood Supplementation with and without Stimulation on Later Development in Stunted Jamaican Children', American Journal of Clinical Nutrition 66: 247-53

Lwambo, N.J.; Brooker, S.; Siza, J.E.; Bundy, D.A. and Guyatt, H. (2000) 'Age Patterns in Stunting and Anaemia in African Schoolchildren: A Cross-sectional Study in Tanzania', European Journal of Clinical Nutrition 54: 36-40

Martorell, R.; Khan, L.K. and Schroeder, D.G. (1994) 'Reversibility of Stunting: Epidemiological Findings in Children from Developing Countries', European Journal of Clinical Nutrition 48.Suppl 1: S45-57

Monyeki, K.D.; Cameron, N. and Getz, B. (2000) 'Growth and Nutritional Status of Rural South African Children 3-10 Years Old: The Ellisras Growth Study', American Journal of Human Biology 12: 42-9

Neufeld, K.J.; Peters, D.H.; Rani, M.; Bonu, S. and Brooner, R.K. (2005) 'Regular Use of Alcohol and Tobacco in India and its Association with Age, Gender, and Poverty', Drug and Alcohol Dependence 77.3: 283-91 
Prasad, R. (2009) 'Alcohol Use on the Rise in India', The Lancet 373.9657: 17-18

Singh, A. (2008) Do School Meals Work?: Treatment Evaluation of the Midday Meal Scheme in India, Young Lives Working Paper Series, Oxford Stoltzfus, R.J.; Albonico, M.; Tielsch, J.M.;

Chwaya, H.M. and Savioli, L. (1997) 'Linear

Growth Retardation in Zanzibari School

Children', Journal of Nutrition 127: 1099-105
Tanner, J.M. (1990) Fetus into Man, Cambridge: Harvard University Press

Tanner, J.M. (1986) 'Growth as a Target Seeking Function: Catch-up and Catch-down Growth in Man', in F. Falkner and J.M. Tanner (eds), Human Growth, New York: Plenum Press, Vol 1: 167-79 